\title{
A STUDY OF DRUGS USE AWARENESS AMONG STUDENTS IN KENYA
}

Martin Ogutu ${ }^{1}$, Evans Vidija Sagwa ${ }^{2}$, Vidija Evans ${ }^{3}$

${ }^{1}$ Kenya Medical Training College-Mathare, Nairobi, Kenya

${ }^{2}$ Kenya Medical Training College-Mathare, Nairobi, Kenya

${ }^{3}$ Kenya Medical Training College-Mathare, Nairobi, Kenya

*Corresponding Author: Martin Ogutu

Article Received: $17-06-19$

Accepted: 28-09-19

Published: 05-10-19

Licensing Details: Author retains the right of this article. The article is distributed under the terms of the $\begin{array}{lllll}\text { Creative } & \text { Commons } & \text { Attribution-NonCommercial } & 4.0 & \text { License }\end{array}$ (http://www.creativecommons.org/licences/by-nc/4.0/) which permits non-commercial use, reproduction and distribution of the work without further permission provided the original work is attributed as specified on the Journal open access page

\section{ABSTRACT}

The study aims to assess the substance use related literacy among the medical students in government based medical college in the Nairobi, Kenya. The methodology of the study was cross sectional based on survey method. Result states that majority of students reported there is presence of substance abusing youths are existed in their classrooms. Results also shows that there is low level of self-intake substance and increase assertiveness as found among medical students.

Keywords: Substance Use, Medical, Students, Health Literacy, Mental Health, Kenya

\section{INTRODUCTION}

The term "mental health literacy" (MHL) is about beliefs and knowledge about mental disorder which aid recognition, management or prevention about something. MHL is about understanding some disorder, understanding when and how to search suitable mental health information, and related causes and risk factor-based knowledge. It also consists of understanding of healthrelated information, risk factors, self-treatments, and seeking professional help $[1,2]$

The college life time is a transitional stage among individuals' development and also contains high risk for initiating substance use. It is estimated that globally, about 1.2 billion individuals 
are victims of substance abuse. At global level, there is increase in use of addictive substance use since now these substances are easily available and mostly individuals adopt using these because of poor company.

Chatterjee et al. [3] stated that the use of substance among university level student is increasing across the world. Common factors leading to this trend include easily availability, desire to be popular rapidly, poor role model, pressure from peer group and experimentation behavior leading to this trend. There is trend of using substance all over the world and this trend is more concentrated among university and college level students $[4,5,6,7,8,9,10,11]$

The alarming facto is that a lot of time, college and university level students and the health professionals have poor knowledge of the negative effects of harmful effects of substance usage $[12,13,14,15,16,17]$. Studies conducted in this domain shows that the substance usage is facilitated because of poor knowledge about its effects ${ }^{[18,19,20,21]}$

\section{Objective}

The objective of the study are as follows;

- To measure the mental health literacy (knowledge and attitude about substance use) among medical college students in a Kenyan medical college.

\section{MATERIALS AND METHODS}

The participants of the study are medical college students in their second, third, and final years studying medical degree program. The first-year student was excluded from the study. We adopted questionnaire named 'Knowledge and Attitude Addiction Questionnaire for Adolescent (KAAQA)' [14]. It is a self-reported survey which is used to measure knowledge about substance use and its effects. The study nature is cross-sectional. The questionnaire consists of 31 statements where individuals are required to answer on dichotomous scale of yes or no. We took informed consent from all participants. The questionnaire was administered on individual basis and through physical distribution and collection back on same day.

\section{Population and Sampling}

For this study, the population represent all medical students, however, we selected only one medical college which is a government-based college in the city of Nairobi, Kenya. We used convenience non-random sampling for data collection.

\section{Statistical Analysis}

We collected data from participants and entered in SPSS version 21. Analysis included frequencies, mean, standard deviation, chi-square test for comparison purpose.

\section{RESULTS AND OBSERVATION}

Table 1: Socio-demographic Details

\begin{tabular}{|l|l|l|l|l|}
\hline Variable & $\begin{array}{l}\text { Male } \\
(\mathbf{N = 2 0 9 )} \\
\text { Frequency }(\%)\end{array}$ & $\begin{array}{l}\text { Female } \\
(\mathbf{N = 2 1 7}) \\
\text { Frequency }(\%)\end{array}$ & $\chi^{\mathbf{2}) \text { value }}$ & P value \\
\hline Marital status: Single & $207(99)$ & $202(93.1)$ & $\mathbf{1 0 . 0 4 8}$ & $\mathbf{0 . 0 0 7}$ \\
\hline
\end{tabular}




\begin{tabular}{|c|c|c|c|c|c|}
\hline & Married & $1(0.5)$ & $4(1.8)$ & & \\
\hline & Engaged & $1(0.5)$ & $11(5.1)$ & & \\
\hline \multirow{4}{*}{ Religion: } & Christian & $202(96.7)$ & 205 (94.5) & \multirow{4}{*}{7.274} & \multirow{4}{*}{0.064} \\
\hline & Muslim & $3(1.4)$ & $7(3.2)$ & & \\
\hline & Hindu & 0 & $4(1.8)$ & & \\
\hline & Others & $4(1.9)$ & $1(0.5)$ & & \\
\hline \multicolumn{2}{|c|}{ Year of study: $2^{\text {nd }}$ year } & $108(51.7)$ & $101(46.5)$ & 0.926 & 0.336 \\
\hline \multirow{3}{*}{ Family type: } & $3^{\text {rd }}$ year & $101(48.3)$ & $116(53.5)$ & & \\
\hline & Nuclear & $142(67.9)$ & $171(78.8)$ & \multirow{2}{*}{5.896} & \multirow{2}{*}{0.015} \\
\hline & Extended & $67(32.1)$ & $46(21.2)$ & & \\
\hline \multirow[t]{2}{*}{ Locality: } & Urban & $172(82.3)$ & $126(58.1)$ & \multirow{2}{*}{28.6} & \multirow{2}{*}{$<0.0001$} \\
\hline & Rural & $37(17.7)$ & $91(41.9)$ & & \\
\hline \multicolumn{6}{|c|}{ Mean Age $($ SD) $=19.66 \pm 1.07$} \\
\hline
\end{tabular}

$\chi^{2}$ test applied between Medical College and Nursing College group Students; P $<0.05$ was considered statistically significant. There were total of 207 male and 202 females participated in the study making total of 426 in the study. Most participants were single in male category (207) as well as in female category (202). Religion wise, most participants were Christians (202) in male category and in female category, there were 205 Christians. The family type was mostly nuclear as 142 participants in male category and 171 participants in female category. Most participants in both male and female category comes from urban areas.

Table 2: Substance use related knowledge and attitude (KAAQA)

\begin{tabular}{|c|c|c|c|c|c|c|c|}
\hline $\begin{array}{c}\text { No } \\
\cdot\end{array}$ & KAAQA Items & $\begin{array}{l}\text { Total Sample } \\
\qquad(\mathrm{N}=\mathbf{4 2 6})\end{array}$ & $\begin{array}{c}\text { Total } \\
\text { Percentage }\end{array}$ & $\begin{array}{c}\text { Male } \\
\text { Students } \\
(\mathbf{N}=\mathbf{2 0 9}) \\
\end{array}$ & $\begin{array}{c}\text { Female } \\
\text { Students } \\
(\mathbf{N}=217) \\
\end{array}$ & $\begin{array}{c}\chi^{2} \\
\text { value }\end{array}$ & $P$ value \\
\hline 1 & $\begin{array}{l}\text { Risk of substance use if staying } \\
\text { with such people }\end{array}$ & 353 & 82.8638 & 165 & 188 & 0.407 & 0.4777 \\
\hline 2 & $\begin{array}{l}\text { Substance use improves memory/ } \\
\text { concentration }\end{array}$ & 376 & 88.2112 & 186 & 190 & 27.917 & $<0.0001$ \\
\hline 3 & $\begin{array}{l}\text { Most of youth starts substances } \\
\text { with peer group }\end{array}$ & 257 & 60.32864 & 48 & 209 & 2.494 & 0.0714 \\
\hline 4 & Substances reduces stress & 284 & 66.66667 & 167 & 117 & 11.27 & 0.0007 \\
\hline 5 & $\begin{array}{l}\text { Substances don't damage health if } \\
\text { used in small amount }\end{array}$ & 219 & 51.40845 & 85 & 134 & 4.411 & 0.0227 \\
\hline 6 & $\begin{array}{l}\text { Most of substance abuser don't } \\
\text { know their harmful } \\
\text { effects }\end{array}$ & 141 & 33.09859 & 65 & 76 & 0.129 & 0.7149 \\
\hline 7 & $\begin{array}{l}\text { It causes liver damage if used for } \\
\text { longer duration }\end{array}$ & 365 & 85.68075 & 187 & 178 & 9.992 & 0.0017 \\
\hline
\end{tabular}




\begin{tabular}{|c|c|c|c|c|c|c|c|}
\hline 8 & $\begin{array}{l}\text { People appear influential/ rich on } \\
\text { consumption of substance }\end{array}$ & 387 & 90.84507 & 198 & 189 & 10.094 & 0.0014 \\
\hline 9 & $\begin{array}{l}\text { One should not take substances } \\
\text { which cause bad effect but one } \\
\text { may take } \\
\text { substances which won't cause } \\
\text { such bad effects }\end{array}$ & 124 & 29.1 & 56 & 68 & 7.701 & 0.0044 \\
\hline 10 & $\begin{array}{l}\text { Chewing tobacco may cause oral } \\
\& \text { throat cancer }\end{array}$ & 177 & 41.5493 & 87 & 90 & 4.914 & 0.0149 \\
\hline 11 & $\begin{array}{l}\text { If one won't feel intoxicated over } \\
\text { consumption of larger amounts it } \\
\text { shows that he is healthy }\end{array}$ & 121 & 28.40376 & 56 & 65 & 19.914 & $<0.0001$ \\
\hline 12 & $\begin{array}{l}\text { Females won't consume any } \\
\text { substance }\end{array}$ & 55 & 12.9108 & 21 & 34 & 10.92 & 0.0009 \\
\hline 13 & There is no treatment for addiction & 52 & 12.20657 & 30 & 22 & 4.942 & 0.0147 \\
\hline 14 & $\begin{array}{l}\text { Substance abusers are bad people } \\
\text { so they should not be helped }\end{array}$ & 59 & 13.84977 & 31 & 28 & 4.717 & 0.0177 \\
\hline 15 & $\begin{array}{l}\text { Majority of substance abuser are } \\
\text { rich people }\end{array}$ & 94 & 22.06573 & 45 & 49 & 44.927 & 0.0001 \\
\hline 16 & Injecting drugs may cause HIV & 122 & 28.6385 & 54 & 68 & 17.14 & 0.0001 \\
\hline 17 & $\begin{array}{l}\text { Most of youth don't take any } \\
\text { substance }\end{array}$ & 334 & 78.40376 & 165 & 169 & 0.142 & 0.7044 \\
\hline 18 & $\begin{array}{l}\text { Willful subjects may quit } \\
\text { substance any time despite longer } \\
\text { intake of substance }\end{array}$ & 166 & 38.96714 & 88 & 78 & 0.441 & 0.4019 \\
\hline 19 & Drugs increases pleasure of life & 341 & 80.04695 & 178 & 163 & 19.197 & 0.0001 \\
\hline 20 & $\begin{array}{l}\text { One should take substance at least } \\
\text { once just to understand that it } \\
\text { causes damage }\end{array}$ & 343 & 80.51643 & 180 & 163 & 11.492 & 0.0007 \\
\hline 21 & $\begin{array}{l}\text { If someone takes substance at } \\
\text { home there is more risk for such } \\
\text { intake in family }\end{array}$ & 166 & 38.96714 & 76 & 90 & 0.001 & 0.9772 \\
\hline 22 & $\begin{array}{l}\text { Substance abusing youth are } \\
\text { influential in their peer group }\end{array}$ & 172 & 40.37559 & 90 & 82 & 1.979 & 0.0902 \\
\hline 23 & $\begin{array}{l}\text { Substance abusing youth are more } \\
\text { likely to succeed }\end{array}$ & 289 & 67.84038 & 123 & 166 & 27.17 & $<0.0001$ \\
\hline 24 & $\begin{array}{l}\text { There is no problem in substance } \\
\text { take until it is revealed to others }\end{array}$ & 171 & 40.14085 & 87 & 84 & 19.017 & $<0.0001$ \\
\hline
\end{tabular}




\begin{tabular}{|c|c|c|c|c|c|c|c|}
\hline 25 & $\begin{array}{l}\text { Harmful effects of drugs are only } \\
\text { temporary }\end{array}$ & 120 & 28.16901 & 55 & 65 & 17.707 & $<0.0001$ \\
\hline 26 & $\begin{array}{l}\text { Youth takes substance only when } \\
\text { there is any quarrel between } \\
\text { parents/ peers }\end{array}$ & 99 & 23.23944 & 45 & 54 & 1.429 & 0.1149 \\
\hline 27 & Have you taken any substance? & 116 & 27.23005 & 55 & 61 & 9.701 & 0.0019 \\
\hline 28 & $\begin{array}{l}\text { Does any of your friend takes } \\
\text { substances }\end{array}$ & 80 & 18.77934 & 36 & 44 & 9.971 & 0.0017 \\
\hline 29 & $\begin{array}{l}\text { Does any of your family member } \\
\text { takes substance }\end{array}$ & 147 & 34.50704 & 89 & 58 & 0.219 & 0.4711 \\
\hline 30 & $\begin{array}{l}\text { Do you have confidence to say no } \\
\text { when somebody offers you any } \\
\text { substance }\end{array}$ & 146 & 34.2723 & 90 & 56 & 19.047 & $<0.0001$ \\
\hline 31 & $\begin{array}{l}\text { Do you want to have correct } \\
\text { information regarding how to } \\
\text { prevent substance intake }\end{array}$ & 223 & 52.34742 & 78 & 145 & 1.129 & 0.1971 \\
\hline
\end{tabular}

$\chi^{2}$ test applied between Medical College and Nursing College group Students; P $<0.05$ was considered statistically significant

For item 1, most people (82.8\%) agreed that they face risk of substance use if they stay with such individuals who use substance. For item 2, large proportion (88.2\%) stated that substance use improves their memory. For item 3, majority participants $(60.32 \%)$ started substance because of peer groups. For item 4 , moderate percentage of participants $(66.6 \%)$ considered that substances reduce their stress level. For item 5, minority of participants $(51.4 \%)$ stated that substances do not damage health if used in small amount. For item 6, less participants $(33.0 \%)$ stated that substance abusers do not know the harmful effects of substance. For item 7, majority participants $(85.6 \%)$ stated that they are aware that substance use cause liver damage if used for longer duration. For item 8, most participants $(90.8 \%)$ stated that use of substance makes them appear influential or rich. For item 9, moderate participants $(29.1 \%)$ stated that one should take those substances which do not cause bad effects and do not use substances which causes bad effects. For item 10, moderate participants $(41.5 \%)$ stated that chewing tobacco may cause oral and throat cancer risk. For item 11, minority participants $(28.4 \%)$ stated that if one won't feel intoxicated after consumption of larger amount, it shows that this person is healthy. For item 12, minority participants (12.9\%) stated that female won't consume any substance. For item 13, minority participants (12.2\%) stated that there is no treatment for addiction. For item 14, minority participants $(13.8 \%)$ stated that substance abusers are bad people so they should not be helped. For item 15, minority participants $(22.0 \%)$ stated that majority of substance abusers are rich people. For item 16, majority participants $(28.0 \%)$ stated that injecting drugs may cause risk of HIV. For item 17, minority participants (78.4\%) agreed that most of youth do not take any substance. For item 18, minority participants (38.96\%) stated that individuals are able to quit substance any time even if they are taking it for longer time. For item 19, majority of participants $(80.0 \%)$ stated that drugs increase pleasure of life. For item 20 , minority of participants $(28.87 \%)$ 
stated that one should take substance at least once just to understand that it causes damage. For item 21, minority participants $(38.9 \%)$ that if someone take substance at home, there is risk that family members may start using the substance. For item 22, moderate participants (40.3\%) stated that substance abusing youths are influential in their peer groups. For item 23, majority participants (67.8\%) stated that substance abusing youth are more likely to succeed. For item 24, minority of participants $(40.1 \%)$ stated that there is no problem in substance intake until it is revealed to others. For item 25, minority of participants $(28.1 \%)$ stated that harmful effects of drugs are only temporary. For item 26, minority of participants $(23.2 \%)$ stated that youth takes substance only when there is any quarrel between parents or peers. For item 27, minority of participants $(27.2 \%)$ admitted that they have taken substance. For item 28, minority of participants (18.7\%) agreed that their friends take some substance. For item 29, minority of participants $(34.5 \%)$ stated that their family members take substance. For item 30, minority participants $(34.2 \%)$ stated that they have confidence to say no when somebody offers them some substance. For item 31, moderate participants $(52.3 \%)$ stated that they want correct information about how to prevent substance intake.

\section{Discussion}

Individuals may start using drugs during the college life mainly due to the immature mind, lack of understanding, and influenced by peers. The misconception is that use of substance will help them overcoming some negative things such as stress [22]. It is important to develop suitable strategy to curb substance use among college and university students since it is at this stage where individuals are at risk of start using substance [23]

We found that students we surveyed were mostly aware of the harmful effects of substance such as cancer, liver damage, and throat infections [20,24]. The college student major source of information are friends, teachers, parents, and media [4, 14, 24, 25]. An alarming finding is that most students reported higher risk of substance use due to the peer pressure or staying with induvial who take substances. However, positive sign is that mostly students reported that they are able to say no or like to avoid substance use as they have good knowledge about the negative effects of substance use. Individuals who had personal experience of someone 'with a substance use problem' reported that they had negative attitude [12, 17]. In this study minority of students agreed for taking any substance by themselves $(14.8 \%)$ or by their family members $(27.7 \%)$ and friends (34.1\%) which was similar to another study [20].

Prevention based awareness programs are important to decrease demand by informing students about the relative risks of dependence on various substances based on current knowledge of these risks. As the substance use usually begins after the age of 12 and rises with the increased age, therefore, the preventive substance use disorder education should begin in early adolescence which can deter or delay substance use through changes in knowledge, attitude, and behavior [26, 27, 28, 29, 30] Adolescent substance use education must meet the needs of those not taking any substance as well as those experiencing initial substance 
exposures. Education provided at early age is important in modifying students' responses in substance use situations and in the later age it is most meaningful [27].

Prevention programs should also be targeted to an individual's substance specific educational needs [26, 28] Comprehensive approaches that address behavioral, emotional, and environmental factors are more effective in eliciting long term effects [26, 27, 28, 29, 30].

\section{CONCLUSION AND IMPLICATION}

The conclusion of the study is that among the medical students surveyed, majority of students reported higher risk of substance use due to the staying with such individuals. Majority of students agreed that if they take substance home, it will also be used by some family members. Majority of individuals reported that there is someone in their circle who is using substances. However, it can also be concluded that medical students are aware of the negative effects of substance use

\section{Recommendation}

Our first recommendation is that there is need for development of suitable awareness program for medical college students in order to reduce the risk of substance use among these individuals.

\section{Limitation}

The limitation of the study includes small sample size, single focus of medical college students, single city based sample, and self-reported measure.

\section{References}

1. Jorm, A.F., Korten, A.E., Jacomb, P.A., Christensen, H., Rodgers, B., Pollitt, P. (1997). Mental health literacy": a survey of the public's ability to recognise mental disorders and their beliefs about the effectiveness of treatment. The Medical Journal, 166(4), 182-86.

2. Who India (2003). Adolescents in India: a profile. UNFPA for UN system in India. Available from :http://whoindia.org/LinkFiles/Adolescent_Health_and_Develo pment

3. Chatterjee, S., Tempalski, B., Pouget, E.R., Cooper, H.L., Cleland, C.M., Friedman, S.R. (2011). Changes in the Prevalence of Injection Drug Use Among Adolescents and Young Adults in Large U.S. Metropolitan Areas. AIDS and Behavior, 15, 1570-78.

4. Tsering, D., Pal, R., Dasgupta, A. (2010). Substance use among adolescent high school students in India: a survey of knowledge, attitude and opinion. Journal of Pharmacy and Bioallied Sciences, 2, 137-40.

5. Mohan, D., Thomas, M.G., Prabhu, G.G. (1997). Prevalence of drug abuse in high school population. Indian Journal of Psychiatry,33, 20-24.

6. Verma, V.K., Ghosh, A., Singh, S., Wig, N.N. (1977). Drug abuse among college students in India. Indian Journal of Psychiatry, 19, 1-10.

7. Sethi, B.B., Manchanda, R. (1978). Pattern of drug abuse among male students. Indian Journal of Psychiatry, 20, 166-173.

8. Khan, M.Z., Unnithan, N.P. (1979). Association of socio-economic factors with drug use among college students in an Indian town. Bulletin on Narcotics, 31, 61-69. 
9. Kushwaha, K.P., Singh, Y.D., Rathi, A.K., Singh, K.P., Rastogi, C.K. (1992). Prevalence and Abuse of Psychoactive Substances in Children and Adolescents. Indian Journal of Pediatrics, 59, 261-268.

10. Panicker, R. (1998). Street children and drug abuse in India. In: Drug Demand Reduction Report. UNDCP Regional Office for South Asia, 34-36.

11. Saluja, B.S., Grover, S., Irpati, A.S., Mattoo, S.K., Basu, D. (2007). Drug Dependence in Adolescents 1978-2003: A clinic based observation from North India. Indian Journal of Pediatrics, 74, 455-58.

12. Gassman, R.A., Demone, H.W., Albilal, R. (2001). Alcohol and other drug content in core courses: Encouraging substance abuse assessment. Journal of Social Work Education, 37, 137-45.

13. Warburton, L., Callfas, D., Neubauer, S.L. (2007). Assessment of knowledge and attitude changes in young adolescents following a school-based crystal methamphetamine education program. Canadian Pharmacy Journal, 140, 366-75.

14. Prakash, O.M, Giri. O.P., Mishra, A.K., Kumar, S., Kulhara, P. (2009). Knowledge and attitude of Indian adolescents towards addiction: finding from an exploratory survey. Journal of Mental Health \& Human Behavior, 14, 74-79.

15. Happell, B., Carta, B., Pinikahana, J. (2002). Nurses' knowledge, attitudes and beliefs regarding substance use: A questionnaire survey. Nursing and Health Sciences, 4, 193200 .

16. Heckman, C.J., Dykstra,J.L, Collins, B.N. (2010). Substance-related knowledge, attitude, and behaviour among college students: Opportunities for health education. Health Education Journal, 20, 1-17

17. Bryan, A., Moran, R., Farrell, E., O'Brien, M. (2000). Drug-Related Knowledge, Attitudes and Beliefs in Ireland: Report of a Nation-Wide Survey. Dublin: The Health Research Board.

18. Giannetti, V.J., Sieppert, J.D., Holosko, M.J. (2002). Attitudes and knowledge concerning alcohol abuse: Curriculum implications. Journal of Health and Social Policy, 15, 45-58.

19. Moreira, F.G, Silveira, D.X., Andreoli, S.B. (2009). Knowledge and attitudes related to drug abuse and prevention dis-played by public school educators. Rev Bras Psiquiatr, 31, 95-100.

20. Nebhinani, N., Mamta, N., Misra, A.K., Garewal, S. (2013). Substance-Related Knowledge and Attitude In School and College Students: A School Based Survey. German Journal of Psychiatry, 16(1), 15-19.

21. Nebhinani, N., Mamta, Misra,.K., Kaur, M. (2013). Knowledge and Attitude about Substance Use in School Students. Indian Journal of Social Psychiatry, 29(3-4), 114-18

22. O'Malley, P.M., Johnston, L.D., Bachman, J.G. (1998). Alcohol use among adolescents. Alcohol Health Research World, 22, 85-93. 
23. Moreira, F.G., Silveira, D.X., Andreoli, S.B. (2009). Knowledge and attitudes related to drug abuse and prevention dis-played by public school educators. Rev Bras Psiquiatr, 31, 95-100.

24. Haddad, L,. Shotar, A., Umlauf, M., Al-Zyoud, S. (2010). Knowledge of Substance Abuse Among High School Students in Jordan. Journal of Transcultural Nursing, 21, 143-150.

25. Linda, H., Ali, S., Mary, U., Sukaina, A.Z. (2010). Knowledge of substance abuse among high school students in Jordan. Journal of Transcultural Nursing, 21, 143-150.

26. White, D., Pitts, M. (1998). Educating young people about drugs: a systematic review. Addiction, 93, 1475-87.

27. Tobler, N.S., Lessard, T., Marshall, D. (1999). Effectiveness of school-based drug prevention programs for marijuana use. School Psychology International, 20, 105-37.

28. Black, D.R., Tobler, N.S, Sciacca, J.P. (1998). Peer helping/involvement: an efficacious way to meet the challenge of reducing alcohol, tobacco, and other drug use among youth. Journal of School Health, 68(3), 87-93.

29. McBride, N. (2003). A systematic review of school drug education. Health Education Research, 18, 729-42.

30. Lilja, J., Wilhelmsen, B.U., Larsson, S., Hamilton, D. (2003). Evaluation of drug use prevention programs directed at adolescents. Substance Use \& Misuse, 38(11-13), 18316 